\title{
METHODOLOGY
}

\section{A simple method for the detection of recombinogenic substances in filamentous fungi}

\author{
Marta dos Santos Baracho and Ivanhoé Rodrigues Baracho
}

\begin{abstract}
\section{INTRODUCTION}

Some fungal strains display an instability, which manifests with appearance of sectors different from the rest of the colony. This instability frequently originates from genetic changes in the mycelium, such as mitotic recombination, separation of nuclei in heterokaryons and chromosomal losses during haploidization. Chemical and physical agents, and even genetic factors, can alter the normal pattern of instability, in strains with chromosomal duplication (Cooke et al., 1970; Palmer and Roper, 1970; Lee and Nga, 1973; Rosato, 1973; Menezes, 1974; Parag and Roper, 1975; Bonatelli Jr. and Azevedo, 1977; Azevedo et al., 1977; Rosato and Azevedo, 1978; Majerfeld and Roper, 1978; Gabrielli and Azevedo, 1980).

The aim of this study was to assess the applicability of circular statistics in studying the effect of drugs on a duplication strain of Aspergillus nidulans. Since this fungus forms circular colonies when grown on solid medium, and since the point of appearance of sectors, in these colonies, can be determined, sector analysis by circular statistics should be possible. This method of analysis may facilitate the study of drugs with mutagenic and recombinogenic effects on A. nidulans.
\end{abstract}

Several tests are available for detecting mutagenic and recombinogenic products in fungi. Since fungi are eukaryotic, these tests permit the detection of substances that produce chromosomal aberrations, or that are recombinogenic. We have developed a new method for testing substances that affect fungal stability using a duplication strain of Aspergillus nidulans and circular statistics for data analysis. The fungus was inoculated on the center of Petri dishes and the substance to be tested was applied to a defined area of the dish. Position of resulting sectors was measured by an angle and the data were analyzed by the Rayleigh test. Extensive testing with different compounds showed this method to be rapid and efficient for screening recombinogenic substances.

\section{MATERIAL AND METHODS}

A duplication strain of A. nidulans (strain A; Nga and Roper, 1968) was used. This strain carries a segment in duplicate of chromosome I translocated to chromosome II, has a characteristic "crinkled" morphology and reduced growth rate and is unstable, producing sectors of various kinds (Azevedo and Roper, 1970). Petri dishes measuring $9 \mathrm{~cm}$ in diameter were filled with solid medium (Pontecorvo et al., 1953). The center and diameter of each plate were marked on the outside and the 0 -degree angle was indicated on the left of the center. The fungus was inoculated into the center of the dishes, which were then incubated for 7 days at $37^{\circ} \mathrm{C}$.

After 7 days, the dishes were examined for the formation of sectors and, when present, the type and angle formed by the diameter and by a line traced from the center of the dish to the origin of the sectors were recorded. This angle was measured with a protractor on the under side of the dish (back of the colony) in a clockwise direction.

When the effects of chemical compounds were tested, a line was drawn parallel to and $2.0 \mathrm{~cm}$ from the diameter (Figure 1). The test compound was then added with a brush to the area of the culture medium defined by this line and the border of the dish. Following inoculation of the fungus, the dish was incubated as above.

The following solutions were used in different experiments:

Experiment 1 - control

Experiment 2 - Chloroneb solution: $0.25 \mathrm{mg}$ Chloroneb supplemented with $25 \mathrm{ml}$ methanol. Two milliliters of this solution was added to $2 \mathrm{ml}$ of $0.9 \%$ saline.

Experiment 3 - Benlate solution: $0.25 \mathrm{mg}$ Benlate dissolved in $25 \mathrm{ml}$ acetone. One milliliter of this solution was added to $2 \mathrm{ml}$ of $0.9 \%$ saline.

Experiment 4 - Vitavax solution: $0.4 \mathrm{mg}$ Vitavax was added to $1 \mathrm{ml}$ acetone and $25 \mathrm{ml}$ of sterilized water.

All solutions were sterilized in a water bath at $60^{\circ} \mathrm{C}$ for $15 \mathrm{~min}$ on three consecutive days. 


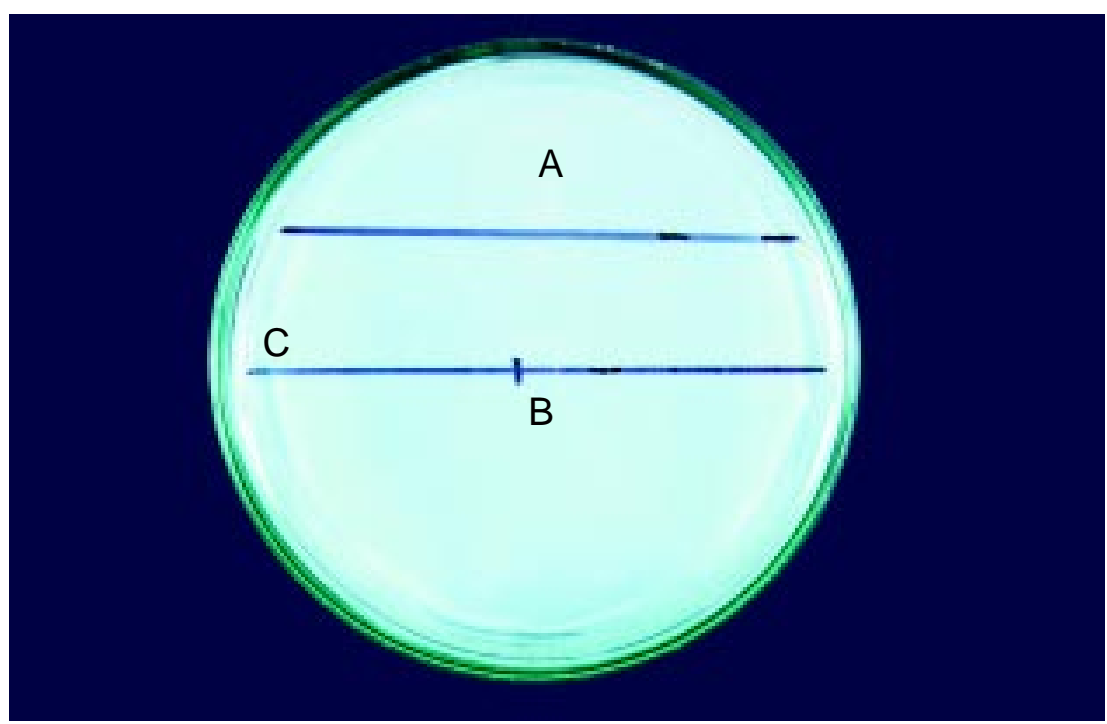

Figure 1 - Photo of a Petri dish that shows: $\mathbf{A}$, area where the drug is placed; $\mathbf{B}$, center and diameter and $\mathbf{C}, 0$-degree angle.

\section{Statistical analysis}

The experiments were analyzed statistically using the circular statistics method, since we determined the direction in which the sectors spread out from the circular colonies. The circular distribution generally originates from observation of the direction in which these sectors arise, without considering the distance between them and the center of the colony.

The data were analyzed statistically by the Rayleigh test (Rayleigh, 1919 a,b), as described by Greenwood and Durand (1955). The concentration around a preferred direction can be measured by the length of the mean vector, which is denoted $\rho$ for the population and $\mathrm{r}$ for a sample. Some of the notations used are defined below. If $\alpha_{1}$, $\alpha_{2}, \ldots \ldots \alpha_{n}$ is a random sample, we consider the $n$ unit vectors with components $\cos \alpha_{i}$ and $\sin \alpha_{i}$. The components and length of the resultant vector are then

$$
\mathrm{V}=\sum_{\mathrm{i}=1}^{\mathrm{n}} \cos \alpha_{\mathrm{i}}, \mathrm{W}=\sum_{\mathrm{i}=1}^{\mathrm{n}} \sin \alpha_{\mathrm{i}}, \text { and } \mathrm{R}=\sqrt{\mathrm{V}^{2}+\mathrm{W}^{2}}
$$

If we divide these quantities by $n$, we obtain the components and length of the mean vector, namely

$$
\mathrm{x}=\mathrm{V} / \mathrm{n}, \mathrm{y}=\mathrm{W} / \mathrm{n} \text {, and } \mathrm{r}=\mathrm{R} / \mathrm{n}
$$

The Rayleigh test is R, or, for greater convenience:

$$
\mathrm{Z}=\frac{\mathrm{R}^{2}}{\mathrm{n}}
$$

which may be written as:

$$
\mathrm{Z}=\mathrm{n} \cdot \mathrm{r}^{2}
$$

Greenwood and Durand (1955) published tables with the critical values of $Z p$ at the 5 and $1 \%$ probability levels. The conclusion of the Rayleigh test is that if $\mathrm{Z}>\mathrm{Zp}$, the null hypothesis of distribution is rejected, i.e., $\rho$ is significantly different from zero. However, if the opposite is true, i.e., $Z \leq Z p$, then the assumption of $\rho=0$ is consistent with the data.

\section{RESULTS AND CONCLUSION}

Spontaneous sectors appearing in the duplication strain of A. nidulans were analyzed to determine whether the appearance of sectors differed from a uniform circular distribution (Experiment 1 in Table I). The Rayleigh test showed a non-significant $Z$ value (Table II).

Some agricultural fungicides act on the instability of $A$. nidulans by altering the frequency of sectoring in duplication strains. Such agents include Benlate, Chloroneb and Vitavax, all of which were tested here.

The active principle of Benlate is benomyl (methyl 1-(butyl carbamoyl)-2 benzimidazole carbamate). The action of this compound on A. nidulans instability was studied by Hastie (1972) and Edwards et al. (1985), who noted that this fungicide increased the onset of sectors. Analysis of the effect of Benlate by the method described here yielded the data shown in Experiment 2 of Table I. The Rayleigh test gave a $Z$ value of 7.18 for these data. This highly significant value confirmed the ability of the drug to increase the number of sectors.

Chloroneb (1-4-dichloro-2,5-dimethoxybenzene) is the active principle of Demosan. Kappas and Geogopoulos (1975) and Geogopoulos et al. (1976) studied the action of Chloroneb on the instability of $A$. nidulans strains and noted that the fungicide caused non-disjunction. Azevedo et al. (1977) observed that Chloroneb increased the number 
Table I - Direction of sector appearance in strain A of Aspergillus nidulans.

\begin{tabular}{|c|c|c|c|c|c|c|c|}
\hline \multicolumn{2}{|c|}{$\begin{array}{c}\text { Experiment } 1 \\
\text { With no drug }\end{array}$} & \multicolumn{2}{|c|}{$\begin{array}{c}\text { Experiment } 2 \\
\text { Benlate }\end{array}$} & \multicolumn{2}{|c|}{$\begin{array}{c}\text { Experiment } 3 \\
\text { Chloroneb }\end{array}$} & \multicolumn{2}{|c|}{$\begin{array}{l}\text { Experiment } 4 \\
\quad \text { Vitavax }\end{array}$} \\
\hline Dish & Angle (*) & Dish & Angle & Dish & Angle & Dish & Angle \\
\hline 1 & 66 & 1 & 91 & 1 & 206 & 1 & 177 \\
\hline 1 & 321 & 1 & 115 & 2 & 105 & 2 & 256 \\
\hline 2 & 45 & 1 & 149 & 3 & 82 & 3 & 128 \\
\hline 2 & 313 & 1 & 162 & 3 & 141 & 3 & 209 \\
\hline 3 & 83 & 2 & 23 & 4 & 17 & 4 & 206 \\
\hline 3 & 65 & 2 & 71 & 4 & 69 & 4 & 304 \\
\hline 4 & 345 & 2 & 169 & 4 & 95 & 5 & 225 \\
\hline 5 & 81 & 2 & 350 & 4 & 111 & & \\
\hline 5 & 130 & 3 & 2 & 4 & 143 & & \\
\hline 6 & 205 & 3 & 7 & 4 & 171 & & \\
\hline 6 & 237 & 3 & 13 & 4 & 193 & & \\
\hline 6 & 285 & 3 & 39 & 5 & 14 & & \\
\hline 7 & 36 & 3 & 87 & 5 & 35 & & \\
\hline 8 & 345 & 3 & 119 & 5 & 162 & & \\
\hline 9 & 105 & 3 & 175 & & & & \\
\hline 9 & 305 & 3 & 195 & & & & \\
\hline 10 & 41 & 3 & 356 & & & & \\
\hline 11 & 127 & 4 & 70 & & & & \\
\hline 11 & 267 & 4 & 131 & & & & \\
\hline 12 & 6 & 4 & 145 & & & & \\
\hline 12 & 159 & 5 & 18 & & & & \\
\hline 12 & 176 & 5 & 62 & & & & \\
\hline 12 & 198 & 5 & 91 & & & & \\
\hline 13 & 5 & 5 & 128 & & & & \\
\hline 14 & 7 & 5 & 179 & & & & \\
\hline 14 & 41 & 6 & 52 & & & & \\
\hline 14 & 94 & 6 & 80 & & & & \\
\hline 14 & 317 & & & & & & \\
\hline 15 & 67 & & & & & & \\
\hline 15 & 90 & & & & & & \\
\hline 15 & 209 & & & & & & \\
\hline 15 & 275 & & & & & & \\
\hline 16 & 87 & & & & & & \\
\hline 16 & 142 & & & & & & \\
\hline 16 & 217 & & & & & & \\
\hline 16 & 264 & & & & & & \\
\hline 17 & 177 & & & & & & \\
\hline 17 & 17 & & & & & & \\
\hline
\end{tabular}

*In degrees.

Table II - Rayleigh test for the data in Table I.

\begin{tabular}{|crrrr|}
\hline & \multicolumn{4}{c}{ Sum of } \\
\cline { 3 - 4 } Experiment & $\mathrm{N}$ & Sine & Cosine & $\mathrm{Z}$ \\
\hline 1 & 38 & 4.56 & 3.03 & 0.74 n.s. \\
2 & 27 & 13.76 & 2.10 & $7.18^{*}$ \\
3 & 14 & 6.96 & -2.84 & $4.04^{*}$ \\
4 & 7 & -2.36 & 6.36 & $6.74^{*}$ \\
\hline
\end{tabular}

n.s. $=$ Nonsignificant $; *$ significant at the $5 \%$ level.

of sectors in duplication strains. The data for Chloroneb obtained in the present study are presented in Experiment 3 of Table I. The corresponding statistical analysis (Table II) yielded a $Z$ value equal to 4.04 , which corresponds to a significant effect in increasing the number of sectors.
Vitavax, the active principle of which is carboxin $(2,3$ dihydro-5-carboxanilido-6-methyl-1,4-oxathiin), is a fungicide that is particularly toxic to basidiomycetes (Edginton and Barron, 1967; Snel et al., 1970). Azevedo et al. (1977) studied the action of Vitavax on A. nidulans instability and observed that the compound reduced both mitotic recombination in diploids and the instability of duplication strains. The data obtained for Vitavax are summarized in Experiment 4 of Table I and statistical analysis of the data is shown in Table II. The $\mathrm{Z}$ value for these data was 6.74 , indicating a significant effect of the drug in decreasing the number of sectors.

The above results are consistent with those in the literature. The use of circular statistics is fully justified for the analysis of substances that act on the instability of filamentous fungi since in colonies treated to inhibit or stimulate the appearance of sectors at specific points, the appearance of sectors did not correspond to a uniform circular distribution.

The method reported here is rapid and appropriate for testing substances that affect the instability of filamentous fungi, i.e., substances that are mutagenic and recombinogenic.

\section{ACKNOWLEDGMENTS}

This work was supported by CAPES (Brazil). Publication supported by FAPESP.

\section{RESUMO}

Muitos são os testes conhecidos para detectar produtos mutagênicos e recombinogênicos em fungos. Pelo fato de os fungos serem eucarióticos, estes testes permitem detectar não só substâncias que produzem aberrações cromossômicas, mas também substâncias recombinogênicas. Este trabalho apresenta um novo método para testar substâncias que afetam a instabilidade de fungos. A metodologia proposta fez uso de uma linhagem duplicada de Aspergillus nidulans e empregou a estatística circular para análise dos dados. O fungo foi inoculado no centro de placas de Petri e em uma das extremidades da placa foi pincelada a substância a ser testada. $\mathrm{O}$ ângulo de aparecimento de setores foi medido e os dados analisados pelo teste de Rayleigh. O método utilizado revelou-se um método rápido e adequado para testar substâncias recombinogênicas. Ele foi amplamente testado, utilizando várias substâncias.

\section{REFERENCES}

Azevedo, J.L. and Roper, J.A. (1970). Mitotic non-conformity in Aspergillus: successive and transposable genetic changes. Genet. Res. 16: 79-93.

Azevedo, J.L., Santana, E.P. and Bonatelli Jr., R. (1977). Resistance and mitotic instability to chloroneb and 1,4-oxathiin in Aspergillus nidulans. Mutat. Res. 48: 163-172.

Bonatelli Jr., R. and Azevedo, J.L. (1977). Effects of ethidium bromide in diploid and duplication strains of Aspergillus nidulans. Experientia 33:311-312.

Cooke, P., Roper J.A. and Watmough, W. (1970). Trypan blue-induced deletions in duplication strains of Aspergillus nidulans. Nature 226: 
276-277.

Edginton, L.V. and Barron, G.L. (1967). Fungitoxic spectrum of oxathiin compounds. Phytopathol. 57: 1256-1257.

Edwards, G.F.S.L., Normansell, I.D. and Holt, G. (1985). Benlate induced haploidization in diploid strains of Aspergillus nidulans and Penicillium chryosgenum. Asp. News Letter I: 12 (Abstract).

Gabrielli, A.C. and Azevedo, J.L. (1980). A strain of Aspergillus nidulans producing a high frequency of disomics. Trans. Br. Mycol. Soc. 75: 15-20.

Geogopoulos, S.G., Kappas, A. and Hastie, A.C. (1976). Induced sectoring in diploid Aspergillus nidulans as a criterion of fungitoxicity by interference with hereditary processes. Phytopathol. 66: 217-220.

Greenwood, J.A. and Durand, D. (1955). The distribution of the length and components of sum of $\mathrm{n}$ randon unit vectors. Ann. Math. Stat. 26: 233 246.

Hastie, A.C. (1972). Benlate-induced instability of Aspergillus diploids. Nature 226: 771 .

Kappas, A. and Geogopoulos, S.G. (1975). Fungicides causing mitotic segregation in Aspergillus diploids. Mutat. Res. 26: 236.

Lee,Y.T. and Nga, B.H. (1973). Meiotic segregation behavior of translocation haploids in Aspergillus nidulans. Genetics 74 (Suppl.): 153-154

Majerfeld, I.H. and Roper, J.A. (1978). The effects of coumarin on the frequency of deletions in a duplication strain of Aspergillus nidulans. Mol. Gen. Genet. 159: 203-206.

Menezes, E.M. (1974). Análise genética de variantes deteriorados e suas reversões em Aspergillus nidulans. Master thesis, ESALQ-USP, Piracicaba, SP.

Nga, B.H. and Roper, J.A. (1968). Quantitative intrachromosomal changes arising at mitoses in Aspergillus nidulans. Genetics 58: 193-209.

Palmer, L.M. and Roper, J.A. (1970). Induced deletions in duplication strain of Aspergillus nidulans. Asp. News Letter 11: 20 (Abstract).

Parag, Y. and Roper, J.A. (1975). Genetic control of chromosome instability in Aspergillus nidulans as a means for gene amplification in eukaryotic microorganisms. Mol. Gen. Genet. 140: 275-287.

Pontecorvo, G. Roper, J.A., Hemmons, L.M., Donald, K.D. and Bufton, A.W. (1953). The genetics of Aspergillus nidulans. Adv. Genet. 5: 141-238.

Rayleigh, Lord (= Strutt, J.W. 1919a). On the problem of random vibrations and of random flights in one, two or three dimensions. Phil. Mag. 6th Ser. 37: 321-347 (also Sci. Papers 6: 604-626)

Rayleigh, Lord (= Strutt, J.W. 1919b). On the resultant of a number of unit vibrations whose phases are at random over a range not limited to an integral number of periods. Phil. Mag. 6th Ser. 37: 498-515 (also. Sci. Papers 6: 627-641).

Rosato, Y.B. (1973). Efeitos do etil-metano-sulfonato e acriflavina na instabilidade mitótica em Aspergillus nidulans. Master thesis, ESALQ, Piracicaba, SP.

Rosato, Y.B. and Azevedo, J.L. (1978). Acriflavine and ethyl methanesulfonate-induced mutants of Aspergillus nidulans strains with chromosome duplication. Rev. Bras. Genet. I: 247-262.

Snel, M.B., Schemeling von, B. and Edginton, L.V. (1970). Fungitoxicity and structure activity relationships of some oxathiin and thiazole derivatives. Phytopathol. 60: 1164-1169.

(Received October 20, 1999) 